\begin{tabular}{l||c|c}
\hline \hline \multirow{2}{*}{\begin{tabular}{c|c|} 
Researeh Studies \\
Anatolia Journal
\end{tabular}} & R\&S - RESEARCH STUDIES ANATOLIA JOURNAL \\
\hline
\end{tabular}

SOCIAL AND HUMAN SCIENTIFIC

Ertürkmen, G., Bolat, İ. (2020). “Türkiye'deki Özel Sermayeli Mevduat Bankaları ile Katılım Bankalarının Aktif Kalitesi ve Kârlılık Oranlarının Karşılaştırılması Üzerine Bir Araștırma", R\&S - Research Studies Anatolia Journal, Vol:3 Issue:1 ; pp: 19-36

Anahtar Kelimeler: Katılım Bankaları, Özel Keywords: Participation Banks, Private Capital Deposit Sermayeli Mevduat Bankaları, Veri Zarflama Analizi Banks, Data Envelopment Analysis (DEA), Malmquist (VZA), Malmquist İndex, Süper Etkinlik Index, Super Efficiency

Makale Türü Araștırma Makalesi

\title{
TÜRKIYE'DEKİ ÖZEL SERMAYELİ MEVDUAT BANKALARI İLE KATILIM BANKALARININ AKTIF KALİTESİ VE KÂRLILIK ORANLARININ KARŞILAŞTIRILMASI ÜZERİNE BİR ARAŞTIRMA
}

\section{A Research in Turkey of Private Capital Deposit Banks with Participation Banks on Asset Quality and Profitability Ratios}

\section{Gülferah ERTÜRKMEN1}

İsmet BOLAT ${ }^{2}$

\author{
Geliş Tarihi / Arrived Date \\ 07.01.2020
}

Kabul Tarihi / Accepted Date 23.01.2020

\author{
Yayınlanma Tarihi / Published \\ Date \\ 31.01.2020
}

\begin{tabular}{l} 
öz \\
\hline Bu araştırmanın amacı, Türkiye'deki katılım \\
bankaları ile özel sermayeli mevduat bankalarının \\
aktif kalitesi ile kârlılı oranları açısından \\
etkinliklerinin araştırılmasıdır. Araştırmaya konu \\
olan veriler Türkiye Bankalar Birliği (TBB) ve Türkiye \\
Katılım Bankaları Birliği (TKBB) veri setine kayıtlı, 3 \\
katılım bankası ve 9 özel sermayeli mevduat \\
bankasından elde edilmiştir. Elde edilen veriler Veri \\
Zarflama Analizi (VZA), Malmquist toplam faktör \\
verimlilik endeksi ve süper etkinlik analiz teknikleri \\
ile değerlendirilmiştir. Yapılan etkinlik analizi ve \\
verimlilik endeksi sonuçları şu şekildedir: katılım \\
bankalarının hiçbiri ortalama değer bazında \\
Malmquist endeksine göre yeterli etkinliği \\
yakalayamamıştır. Özel sermayeli mevduat \\
bankalarından ise sadece bir banka endeks değerine \\
göre etkin çıkmıștır. İncelenen bankaların BCC-I \\
etkinlik sonuçlarına göre, analize dâhil edilen katılım \\
bankalarının incelenen yıllarda etkinlik skoruna \\
ulaştıkları yıl sayısı, etkinlik skoruna ulaşamadıkları \\
yıl sayısından fazladır. Özel sermayeli mevduat \\
bankalarının çoğunluğunun incelenen yllarda yeterli \\
etkinlik skoruna ulaşamadıkları gözlemlenmiştir.
\end{tabular}

ABSTRACT

The purpose of this research is private capital deposit banks with the participation banks in Turkey investigate the effectiveness in terms of profitability ratios and asset quality of banks. Data is subject to the Banks Association of Turkey (TBB) and the Participation Banks Association of Turkey (TKBB) registered in the data set were obtained from 3 participation bank and 9 private capital deposit banks. The data were evaluated with Data Envelopment Analysis (DEA), Malmquist total factor productivity index and super efficiency analysis techniques. The results of the efficiency analysis and productivity index are as follows: none of the participation banks has achieved sufficient efficiency according to the Malmquist index on average value basis. On the other hand, only one bank from private capital deposit banks was effective according to the index value. According to the BCC-I activity results of the examined banks, the number of years in which the participation banks included in the analysis reached the activity score in the examined years is more than the number of years in which they did not reach the activity score. It has been observed that the majority of private deposit banks have not achieved sufficient efficiency score in the examined years.

iD Dr. Öğr. Üyesi, Kahramanmaraş Sütçü İmam Üniversitesi, Göksun Uygulamalı Bilimler Yüksekokulu, gbozkaya@ksu.edu.tr, Kahramanmaraş /TÜRKIYE

2 iD Öğr.Gör.Dr., Kahramanmaraş Sütçü İmam Üniversitesi, Göksun Meslek Yüksekokulu, ibolat@ksu.edu.tr, Kahramanmaraş/TÜRKIYE 


\section{GíRiş}

Günümüzde ülke ekonomilerinde bankalar ve bankacılık sisteminin önemi gittikçe artmaktadır. Zira bankalar yarattıkları ekonomik büyüklükle ülkelerdeki para akışına yön vermektedirler. Bankaların temel görevi mevduat toplamak ve toplanan bu mevduatları kredi olarak piyasalara dağıtmaktır. Bankalar bunun dışında kaynaklara akıcılık sağlama, maddi varlıkların rasyonel bir biçimde dağılması, kaynak kullanımı iyileştirme, kaydi para yaratma, para politikasının etkinliğini arttırma gibi faaliyetleri de yürütmektedirler.

Son zamanlarda bankacılık sektöründe görülen hızlı gelişmeler ülkelerin ticari, sosyal ve ekonomik yapılarını da önemli öcüde etkilemiştir. Özellikle toplumsal yaşam içerisinde paranın fonksiyonları arttıkça, bankacılık sektörü de gelişme göstererek, günümüzdeki düzeye ulaşmıştır (Arslan ve Hotamışli, 2007:196).

Türkiye'de bankalar faaliyet türlerine göre çeşitli şekillerde isimlendirilirler. Katılım bankaları dediğimiz faizsiz bankaların çalışma prensipleri İslami esaslara göre düzenlenmiştir.

Katılım bankacılığının mantığında tasarruf sahiplerinden toplanan fonların faizsiz finans modeline uygun olarak değerlendirilmesi ve oluşan kar-zararın tasarruf sahipleriyle paylaşılması vardır. Faizsiz bankacılık ilk olarak 1963-1967 yılları arasında Mısır'da başlamıştır. 1971 yılında ilk faizsiz banka kurulmuştur. Türkiye'de faizsiz bankacılık faaliyetlerine ilişkin yasa 1983 yılında çıkmış ve ilk faizsiz bankalar "Özel Finans Kurumu" adıyla 1985 yılında kurulmuştur. 1999 yılında katılım bankalarıyla ilgili ilk düzenlemeler yapılarak Bankacılık Kanunu kapsamına alınmıștır. 2005 yılındaki düzenleme ile de isimleri "Özel Finans Kurumu" iken "Katılım Bankası" olarak değiştirilmiştir(Yurttadur, Demirbaş, 2017:90).

Katılım bankalarında esas olan; Faizsizlik Prensibinin özü aşağıdaki gibidir;

- Fon toplarken herhangi bir sabit getiri taahhüdünde bulunmamak, oluşacak karı/zararı belli bir paylaşım oranında müşteri ile bölüşmek,

- Nakit kredi kullandırmayıp, bir malı veya hizmeti peşin alıp vadeli satmak veya ortaklık yapmak,

- Her türlü bankacılık hizmetinde faizden kesinlikle kaçınmak (Hazıroğlu, 2016:123).

Özetle, katılım bankaları alternatif finansman hizmetleri sunan, finansal sektörde faaliyette bulunan, reel ekonomiyi finanse eden ve bankacılık hizmetleri sunan kuruluşlardır. Temel bankacılık hizmetlerinin yanı sıra, tasarruf sahiplerinden cari hesap ve kâr-zarar ortaklığı hesapları yoluyla topladıkları fonları, faizsiz finansman ilkelerine göre reel sektöre aktararak, oluşan kâr veya zararı tasarruf sahipleriyle paylaşmaktadırlar (Tunç, 2000:13).

Mevduat bankaları özellikle reel sektörle ilişkilerinin de belirleyici olması nedeniyle Türkiye ekonomisinde öneme sahip finansal kurumlardır. Sundukları finansman imkânları ve tasarrufları toplama noktasında sahip oldukları tercih edilme durumu, mevduat bankalarını diğer finansal kurumlar arasında daha aktif duruma getirmiştir (Atukalp, 2018:38-39).

Özel Sermayeli Mevduat Bankaları ise; özel kişi ve kuruluşların sahip olduğu, sermayelerinde kamu payı bulunmayan bankalardır. Özel sermayeli bankalar genelde ticaret, yatırım veya mevduat bankası şeklinde kurulurlar (www.bankalar.org).

Sermayelerinin tümü kamu adına hazineye veya diğer kamu tüzel kişilerine ait olan bankalara kamu (devlet) sermayeli bankalar denilmektedir. T.C. Ziraat Bankası, Türkiye Kalkınma Bankası, Halk Bankası ve Türk Eximbank gibi bankalar kamu sermayeli bankalara örnek olarak gösterilebilir. Yabancı sermayeli bankaların kuruluş ve yönetim merkezleri genellikle ülkemiz sınırları dışında bulunur. HSBC Bank, ING Bank ve Citibank gibi bankalar bu gruba örnek verilebilir. Yabancı sermayeli bankalar, sermayelerinin tümü yabancı uyruklu kişi veya kuruluşlara ait olan bankalardır. Özel kişi ve kuruluşların sahip olduğu, sermayelerinde kamu payı bulunmayan bankalardır. Özel sermayeli bankalar genelde ticaret, yatırım veya mevduat bankası şeklinde kurulurlar. Türkiye Garanti Bankası, Anadolubank ve Akbank gibi bankalar, özel sermayeli bankalardır (Arabacı, 2018:28-29). 
Mevduat bankalarının ekonomide finansal aracılık, kaynaklara akıcılık sağlama, kaynak kullanımında etkinlik, kaynaklarda süre ve tutar uyumu sağlama, kaydî para veya banka parası yaratma, para politikasının uygulanmasında etkinlik sağlama ve uluslararası ticareti geliștirme gibi fonksiyonları bulunmaktadır (Atukalp, 2018:39).

\section{LİTERATÜR}

Araştırma konusu ile ilgili literatür incelendiğinde katılım bankaları ve mevduat bankaları konularında çok sayıda çalışmaya rastlanmaktadır. Dolayısıyla bu bölümde alınan literatür örnekleri asıl konu ile dolaylı olarak ilişkili kaynaklardır. Bu şekilde incelenen başlıca çalışmaların kısa özetleri aşağıda kronolojik bir şekilde sunulmaktadır.

Sufian (2007) Malezya'daki İslami bankaların 2001-2004 yılları arası etkinliklerini Veri Zarflama Analizi tekniğini kullanarak analiz etmiş ve sonuç olarak İslami bankaların yeterli etkinlik sonucuna ulaşamadıklarını belirtmiştir.

Ahmad ve AbdulRahman (2012) Malezya'daki geleneksel bankalar ile İslami bankaların etkinliklerini 2003-2007 yılları arasında Veri Zarflama Analizi yöntemiyle incelemişler ve sonuç olarak İslami bankaların, geleneksel bankalara göre, teknolojik ilerleme ve yönetsel etkinlik bakımından daha verimsiz çalıştıkları görülmüştür.

Johnes vd. (2012) tarafından yapılan çalışmada Veri Zarflama Analizi kullanılmış ve geleneksel bankalarla, İslami bankaların etkinlikleri karşılaştırılmıştır. Farklı 19 ülkede yapılan analizler sonucunda, İslami bankalarla geleneksel bankalar arasında etkinlik açısından anlamlı bir fark olmadığı sonucuna varılmıştır.

Saeed vd. (2013) tarafından yapılan çalışmada oran analizi tekniği ve parametrik olmayan Veri Zarflama Analizi tekniği kullanılarak Pakistan'daki İslami ve Geleneksel bankaların etkinliği değerlendirilmiş ve 2007-2011 döneminde 19 banka ele alınmıştır. Çalışma sonucu elde edilen bulgular, her iki yöntemde de geleneksel bankaların İslami bankalardan daha iyi performans gösterdiğini ortaya koymaktadır.

Doğan (2013) tarafından yapılan çalışmada Türkiye'de Bankacılık Sektöründe faaliyette bulunan katılım bankaları ve geleneksel bankaların finansal performansları karşılaştırılmıştır. Yapılan analiz sonucunda geleneksel bankaların katılım bankalarına göre likiditesi, borç ödeme gücü ve sermaye yeterliliği daha yüksek ve riskliliği daha düşük olduğu belirlenmiștir. Bununla birlikte; katılım ve geleneksel bankaların kârlılıkları arasında istatistiksel olarak anlamlı bir farklılık tespit edilememiştir.

Büyükakın ve Kapkara (2016) yılında yaptıkları çalışmalarında 2010-2015 dönemi için Türkiye'de faaliyet gösteren seçilmiş katılım bankalarının finansal yönden etkinliğini belirlemeyi amaçlamışlar ve bu doğrultuda ilgili bankaların bilançolarından elde edilen verilerle girdi ve çıktı seti oluşturulmuşlardır. Veri Zarflama Analizi (VZA) yöntemi uygulanarak katılım bankalarının finansal etkinlik düzeyleri belirlenmeye çalışılmıştır. Modellerin çözüm aşamasında DEAP 2.1 paket programı kullanılmıştır. Bu analiz ile seçilmiş katılım bankalarının çeşitli etkinlik değerleri, ölçek tipleri ve toplam faktör verimlilikleri belirlenmiştir. Analiz sonuçları incelendiğinde, göreceli olarak en etkin faaliyet gösteren bankanın Türkiye Finans Katılım Bankası olduğu görülmüştür.

Algahtani vd. (2017) GCC Bölgesi İslami bankaları ile konvansiyonel bankalarının etkinliklerini, Veri Zarflama Analizi yöntemiyle ölçmüşler ve kriz sırasında İslami bankaların konvansiyonel bankalara göre daha uygun maliyetli çalıştıkları tespit edilmiştir.

Öztürk vd. (2017) yılında yapmış olduğu çalışmalarında katılım bankaları ile mevduat bankalarının 2009-20016 yılları etkinliklerinin VZA ile karşılaştırmış ve mevduat bankalarının etkinliklerinin her yıl artmasına karşın tam etkinlik skorunu yakalayamadıklarını belirtmişlerdir. Katılım bankalarının ise, 2009 yllında \% 90, 2010 yılında \% 92, 2011 yılında \% 94, 2012 ve 2014 ylllarında \% 98, 2013 yılında \% 97, 2016 yılında \% 96, 2015 yılında ise \% 100 etkin olduğu tespit edilmiştir.

Karaca vd. (2019)'nin birlikte yaptıkları araștırmada 2009-2016 yılları arasında Türkiye'de faaliyet gösteren 5 katılım bankasının etkinlik analizi yapılmıştır. 5 katılım bankası için seçilen girdi ve çıktıların etkinlik ölçümü doğrusal planlama kökenli bir analiz türü olan Veri Zarflama Analizi (VZA) 
kullanılarak yapılmıștır. Uygulamada CCR ve BCC etkinlik skorları çıktı odaklı olarak hesaplanmıștır. Sonuçta 2009-2016 yılları arasında Türkiye'deki 5 katılım bankasının genelde etkin oldukları gözlenmiştir. 2016 yılına doğru etkinliklerinin ve aktif büyüklüklerinin arttığı sonucuna ulaşılmıștır.

Sucu (2019) tarafından hazırlanan yüksek lisans tezinde; ulaşılan sonuçlara göre NPL oranı ve bankacılık sektörünün gelişmişlik düzeyi mevduat ve katılım bankalarının finansal performansı üzerinde negatif yönlü etkiye sahiptir. Diğer bağımsız değişkenlerin finansal performansa etkisi ise incelenen banka türüne ve performans ölçütü olan bağımlı değişkene göre farklılık göstermektedir.

\section{ARAŞTIRMA}

\subsection{Araştırmanın Amacı}

Bankalar ülke ekonomilerinde finansal sistemin önemli birer aktörüdür. Türkiye'deki bazı bankalar çalışma esasları bakımından birbirinden ayrılmaktadır. Katılım bankaları faizsiz bankacılık faaliyetlerinde bulunurken, bazı bankalarda özel sermayeli mevduat bankaları olarak ülkemizde faaliyetlerinin sürdürmektedirler. Çalışmada benzer girdi ve çıktıları kullanan katılım bankaları ve özel sermayeli mevduat bankalarından hangilerinin aktif kalitesi ve kârlılık açısından daha etkin çalıştıklarının tespit edilmesi amaçlanmıştır.

\subsection{Araştırmanın Kapsamı ve Yöntemi}

Türkiye'de halen aktif olan 3 katılım bankası ve 9 özel sermayeli mevduat bankasının 2010-2018 yılları arası verileri Türkiye Katılım Bankları Birliği (www.tkbb.org.tr) ve Türkiye Bankalar Birliği (www.tbb.org.tr) veri setlerinden faydalanılarak olușturulmuştur. Analiz yöntemi olarak VZA (Veri Zarflama Analizi), Süper Etkinlik Modeli ve Malmquist Toplam Faktör Verimlilik Endeksi kullanılmıştır. 2019 yılı itibariyle Türkiye'de 6 aktif katılım bankası bulunurken analize 3 katılım bankasının seçilmesinin nedeni, dahil edilmeyen katılım bankalarının (Ziraat katılım, Vakıf katılım ve Emlak katılım) bankalarının seçili dönemlerde 2015 sonrası verilere sahip olmalarından dolayıdır. 2010 yılından önce analize katılan katılım bankalarının da verileri olmadığından dolayı dönem olarak da verilere ulaşılabilen en yüksek aralık (2010-2018) seçilmiştir.

Analizde girdi yönelimli BCC yöntemi, Süper Etkinlik modeli sonuçları her yıl için ayrı ayrı hesaplanmıştır. Malmquist Endeks değerleri tek bir tablo'da 2015-2018 yılları için hesaplanmıştır.

\subsection{Veri Zarflama Analizi ve Süper Etkinlik}

Charnes, Cooper ve Rhodes (1978) tarafından geliştirilen VZA-CCR olarak adlandırılan ilk VZA modeli girdi yönelimli ve ölçeğe sabit getirili (CRS) bir model olarak kabul edilmiştir. Bu yöntem, firmaların verimli üretim sınırını belirlemeye çalışan bir yöntem olarak literatüre geçmiştir. Bu yönteme göre bir firmanın etkinlik sınırına olan radyal mesafesi, verimliliğinin ölçülmesini sağlamaktadır. Önerilen ikinci VZA modeli, VZA-BCC olarak bilinen ölçeğe göre değişken getiri (VRS) hipotezini sunar ve bu yöntem ilk defa (1984) yılında Banker, Charnes ve Cooper, tarafından geliştirilmiştir. Bu iki önemli modelin yanı sıra, literatürde daha az sıklıkta görülen diğer VZA modelleri de vardır. (Paço and Perez, 2013:9). Veri Zarflama Analizi Analiz, banka şubeleri, hastaneler, mağazalar ve birimlerin benzer görevleri yerine getirdiği diğer örnekler gibi örgütsel "birimlerin" göreli verimliliğini karşlaştırır. Bu birimler, benzer çıtılır oluşturmak için girdi olarak adlandırılan benzer kaynakları kullanır (www.banxia.com, 22.12.019). VZA, benzer birimlerin etkinliklerinin değerlendirilmesinde kullanılan doğrusal programlama temelli bir tekniktir (Ersoy, 2018: 480). Bu yöntemde, her firmanın verimlilik puanı bir verimliliğe göre hesaplanır. Verimlilik sınırında yer alan firmalar 1 (veya \% 100) verimlilik puanına sahiptir. Sınırın altında faaliyet gösteren firmaların verimliliği düşüktür ve 1'den (veya\% 100 'den) daha düşük bir puan almaktadırlar. Bu yöntemde firmaların \% 100'den daha yüksek bir verimlilik puanına sahip olamayacaklarını ve etkinlik sınırının üstünde bulunamayacağını unutulmamalıdır (Huguenin, 2012:6).

Yöntem firmaların girdi ve çıtıları için hedef değerler belirleyerek, verimli olabilmeleri için girdilerin ne kadar azaltılması veya çıktıların ne kadar artırılması gerektiğini hesaplar (Huguenin, 2012:5).

Bir firma, belirli girdilerden maksimum çıktı elde edebiliyorsa veya belirli çıtıları üretirken kullanılan girdileri en aza indirebiliyorsa, teknik açıdan verimli kabul edilir. VZA yaklaşımı, girdi-çıtı 
kombinasyonu'nun bir fonksiyonu olarak her bir karar verme biriminin (DMU) etkinliğini ölçer (Ftiti, 2013:289).

Her verme birimindeki etkinsizlik miktarını ve etkinsizliğin nereden kaynaklandığını tanımlayabilmesi yöntemin sahip olduğu önemli bir özellik olarak göze çarpmaktadır. Yöntem etkin olmayan birimlerin etkin birimler gibi bir etkinlik seviyesine ulaşabilmesi için girdiler ve çıtılar yapılaması gereken miktar artırım-azaltımlarına ilişkin bilgiler vermektedir. $\mathrm{Bu}$ yöntemi diğer yöntemlerden ayıran bir diğer önemli özellik ise; çoklu girdi ve çoklu çıktı kullanarak önceden belirlenmiş herhangi bir analitik üretim fonksiyonu varlığının öngörülmesine gereksinim duymadan ölçüm yapabilmesidir (Yaşa, 2008:41-42).

VZA, her bir KVB'yi yalnızca en iyi KVB'lerle karşılaştırmaktadır. En iyi olarak belirlenen bu KVB'ler etkinlik sınırını oluştururken herhangi bir KVB'nin etkinliği bu sınıra göre ölçülmektedir. Yöntem, etkinlik sınırı üzerinde yer alan en iyi KVB'leri görece etkin olarak değerlendirir ve bu birimler referans kümesi olarak ifade edilir. Etkinlik sınırı üzerinde yer almayan diğer KVB'ler ise görece etkin olmayan birimlerdir. VZA, görece etkin olmayan karar verme birimlerinin etkinliklerinin iyileştirilmesi için neler yapılması gerektiği noktasında yöneticilere ve karar vericilere yol gösteren bir yöntemdir (Özden, 2008:169).

Bu yöntemin avantajlarından biri de, örnekteki her bir firmanın değerlendirilebileceği verimlilik sınırını elde etmek için gerçek örnek verilerini kullanmasıdır (Yue, 1992:33).

Verimli birimleri incelemek için süper etkinlik modelini kullanabiliriz. Bu model CCR (BCC) modelinin aksine, verimli birimlerin verimlilik oranını kendi aralarında değerlendirmemizi sağlar (Vincova, 2005:26).

VZA modelleri; girdiye yönelik ya da çlktıya yönelik olarak oluşturulabilir.

CCR modelinin girdiye yönelik olan versiyonu, gözlemlenen girdi değerlerini en aza indirerek aynı seviyede çıktı düzeyine ulaşmaya çalışır. Çıktı odaklı CCR modeli ise; gözlemlenen girdi değerlerinden daha fazlasına ihtiyaç duymadan çıktıları en üst düzeye çıkarmaya çalışır (Seiford and Tone, 2007:41).

\subsection{Malmquist Toplam Faktör Verimlilik Endeksi (MTFVE)}

Malmquist verimlilik endeksi kavramı ilk olarak Malmquist (1953) ve birkaç yazar tarafından parametrik olmayan çerçevede incelenmiş ve geliştirilmiştir. Bir karar verme birimi'nin toplam faktör büyümesini temsil eden bir endekstir, bu endeks çoklu girdi ve çoklu çıktı çerçevesi altında sınır teknolojisinin ilerlemesi veya gerilemesi ile birlikte verimlilikteki ilerlemeyi veya gerilemeyi yansitır. Malmquist endeksi bir DMU'nun verimlilik değişikliğini iki zaman dilimi arasında değerlendirir. Endeks'teki değişimleri "Catch-up" ve "Frontier-shift" terimlerinin ürünü olarak tanımlar. Catch-up, terimi, bir DMU'nun verimliliğini artırmak için elde ettiği dereceyle ilgilidir. Frontier shift (İnovasyon) terimi, iki zaman dilimi arasında DMU'yu çevreleyen verimli sınırlardaki değişikliği yansıtmaktadır (Tone, 2004:203-204).

MTFV Endeksi girdi ve çıktı yönelimli olarak hesaplanabilir. Bu endeks analize dahil edilen yıllardaki karar birimlerinde verimlilik değişiklikleri teknik etkinlik ve teknolojideki değişimlere göre ölçer. Bu iki faktörün çarpımı toplam faktör verimlilik endeksini oluşturmaktadır. Eğer çarpım değeri 1'den yüksek ise karar birimlerinde gelişme, 1'den küçük ise karar birimlerinde gerilemeyi gösterir. Eğer endeks değeri 1'e eșit ise karar birimlerinin verimliliği sabit kalmıştır bir değişiklik yoktur yorumu yapılabilmektedir (Lorcu, 2010: 278-280).

Tablo 1. Araştırmada Kullanılan Girdi- Çıktı Değişkenleri

\begin{tabular}{ll}
\hline \multicolumn{1}{c}{ Girdi Değişkenler } & \multicolumn{1}{c}{ Çıktı Değişkenler } \\
\hline Finansal Varlıklar (Net) / Toplam Varlıklar & Net Dönem Karı (Zararı) / Toplam Aktifler \\
Toplam Krediler ve Alacaklar / Toplam Aktifler & Net Dönem Karı (Zararı) / Özkaynaklar \\
\hline
\end{tabular}




\section{Verilerin Analizi}

Bu başlık altında 2010-2018 yılları arasında analize dahil edilen bankaların VZA kullanılarak ölçeğe göre değişken getiri altında (BCC) girdi değerleri, süper etkinlik değerleri ve Malmquist analiz sonuçları tablolar halinde gösterilmiş ve tabloların altlarına yorumları eklenmiştir.

Tablo 2. Bankaların 2010 Yılı BCC-I Değerleri ve Ölçek Getiri Türleri

\begin{tabular}{lcccc}
\hline \multicolumn{1}{c}{ BCC (Teknik Etkinlik Değeri (2010) } & & \\
\hline \multicolumn{1}{c}{ KVB } & $\begin{array}{c}\text { Etkinlik } \\
\text { Skoru }\end{array}$ & $\begin{array}{c}\text { Referans } \\
\text { Kümesi }\end{array}$ & $\begin{array}{c}\text { Etkinlik } \\
\text { Sırası }\end{array}$ & Ölçek Getiri Türü \\
\hline Albaraka Türk Katılım Bankası A.Ş. & 1 & $\mathrm{~K}-1$ & 1 & Constant \\
Kuveyt Türk Katılım Bankası A.Ş. & 1 & $\mathrm{~K}-2$ & 1 & Constant \\
Türkiye Finans Katılım Bankası A.Ş. & 0.93353 & $\mathrm{~K}-2$ & 8 & Increasing \\
Akbank T.A.Ş. & 1 & $\mathrm{M}-2$ & 1 & Constant \\
Anadolubank A.Ş. & 1 & $\mathrm{M}-3$ & 1 & Constant \\
Şekerbank T.A.Ş. & 0.78538 & $\mathrm{M}-6$ & 10 & Increasing \\
Turkish Bank A.Ş. & 1 & $\mathrm{M}-6$ & 1 & Increasing \\
Türk Ekonomi Bankası A.Ş. & 0.91938 & $\mathrm{M}-6$ & 9 & Increasing \\
Türkiye İş Bankası A.Ş. & 1 & $\mathrm{M}-8$ & 1 & Constant \\
Yapı ve Kredi Bankası A.Ș. & 1 & $\mathrm{M}-9$ & 1 & Constant \\
\hline
\end{tabular}

Tablo 2'de 2010 yılı için, Türkiye'deki katılım bankalarının ve özel sermayeli mevduat bankalarının etkinlik skorları referans kümeleri, etkinlik sıraları ve ölçek getiri türleri gösterilmiștir.

Tabloya göre, 2010 yılında, BCC-I yaklaşımına göre, analize dahil edilen 10 bankadan 7'si yeterli etkinlik skoruna ulaşırken, 3 banka (Türkiye Finans, Şekerbank ve Türk Ekonomi Bankası) yeterli etkinlik skoruna ulaşamamıştır.

Ölçek etkinlik türlerine bakıldığında 2010 yılında hiçbir bankanın ölçeğe göre azalan getiriye (Decreasing) sahip olmadı̆̆ görülmektedir. 6 bankanın ölçek getiri türü ölçeğe göre sabit getirilidir (Constant) yani bu bankalar girdi kadar çıktı üretmektedir. Bu bankalar için ölçek etkinlik türüne göre herhangi bir azaltma ya da arttırmadan bahsedilemez. 4 banka ise ölçeğe göre artan getiriye (Increasing) sahiptir. Yani bu bankalar bir birim girdiyle bir birimden daha fazla çıktı üretebilecekken kaynaklarını verimli kullanamamışlar ve daha az çıtı elde etmişlerdir. Bu bankalar gelişme potansiyellerini daha iyi kullanıp daha fazla çıktı üretebilirler.

Tablo 3. 2010 Yılı Süper Etkinlik Değerleri ve Sıralama

\begin{tabular}{cccc}
\hline & \multicolumn{2}{c}{ Model = Super-BCC-I-2010 } & Banka No \\
\hline Banka Etkinlik Siralaması & Karar Verme Birimi & Banka Skorları & 2 \\
2 & K-2 & 7.4167 & 7 \\
3 & M-6 & 1.32288 & 1 \\
4 & K-1 & 1.27325 & 5 \\
5 & M-3 & 1.11204 & 9 \\
6 & M-8 & 1.04275 & 4 \\
7 & M-2 & 1.02141 & 10 \\
\hline
\end{tabular}

Tablo 3'de görüldüğü gibi, 2010 yılında toplam etkin olan bankalar arasında süper etkinlik modeli kullanılarak bankaların etkinlik sıralaması yeniden belirlenmiştir. Buna göre, Super-BCC-I etkinlik değerlerine göre K-2 kodlu Kuveyt Türk Katılım Bankası A.Ş. en etkin banka olurken etkin bankalar içinde en az etkin olan banka ise M-9 Yapı ve Kredi Bankası A.Ş.'dir. Etkin olmayan KVB'nin süper etkinlik değerleri ile görece etkinlik değerleri birbirine eşit olacağından, bunların etkinlik sıra numarası değişmeyecektir. 0 yüzden etkin olmayan birimler süper etkinliğe dahil edilmemiştir. 
Tablo 4. Bankaların 2011 Yılı BCC-I Değerleri ve Ölçek Getiri Türleri

\begin{tabular}{|c|c|c|c|c|}
\hline \multicolumn{5}{|c|}{ BCC (Teknik Etkinlik Değeri (2011) } \\
\hline KVB & $\begin{array}{l}\text { Etkinlik } \\
\text { Skoru }\end{array}$ & $\begin{array}{l}\text { Referans } \\
\text { Kümesi }\end{array}$ & $\begin{array}{l}\text { Etkinlik } \\
\text { Sırası }\end{array}$ & Ölçek Getiri Türü \\
\hline Albaraka Türk Katılım Bankası A.Ș. & 1 & $\mathrm{~K}-1$ & 1 & Constant \\
\hline $\begin{array}{l}\text { Kuveyt Türk Katılım Bankası A.Ş. } \\
\text { Türkiye Finans Katılım Bankası }\end{array}$ & 1 & $\mathrm{~K}-2$ & 1 & Constant \\
\hline A.Ș. & 1 & $\mathrm{~K}-3$ & 1 & Constant \\
\hline Akbank T.A.Ş. & 1 & M-2 & 1 & Constant \\
\hline Anadolubank A.Ș. & 0.92916 & $\mathrm{~K}-2$ & 8 & Increasing \\
\hline Fibabanka A.Ș. & 0.73216 & $\mathrm{~K}-2$ & 10 & Increasing \\
\hline Șekerbank T.A.Ș. & 0.73747 & M-2 & 9 & Increasing \\
\hline Turkish Bank A.Ș. & 1 & M-6 & 1 & Increasing \\
\hline Türk Ekonomi Bankası A.Ș. & 0.65469 & $\mathrm{~K}-1$ & 11 & Increasing \\
\hline Türkiye İş Bankası A.Ş. & 1 & M-8 & 1 & Constant \\
\hline Yapı ve Kredi Bankası A.Ș. & 1 & M-9 & 1 & Constant \\
\hline
\end{tabular}

Tablo 4'de 2011 yılı BCC-I sonuçlarına göre Türkiye'deki Katılım Bankalarının ve Özel sermayeli mevduat bankalarının etkinlik skorları referans kümeleri, etkinlik sıraları ve ölçek getiri türleri gösterilmiştir.

Tabloya göre 2011 yılında, BCC-I yaklaşımına göre, analize dahil edilen 11 bankadan 7'si yeterli etkinlik skoruna ulaşırken, 4 banka (Anadolubank A.Ş, Fibabanka A.Ş, Şekerbank ve Türk Ekonomi Bankası) yeterli etkinlik skoruna ulaşamamıștır.

Ölçek etkinlik türlerine bakıldığında 2011 yılında hiçbir bankanın ölçeğe göre azalan getiriye (Decreasing) sahip olmadı̆̆ görülmektedir. 6 bankanın ölçek getiri türü ölçeğe göre sabit getirilidir (Constant) yani bu bankalar girdi kadar çıktı üretmektedir. Bu bankalar için ölçek etkinlik türüne göre herhangi bir azaltma ya da arttırmadan bahsedilemez. 5 banka ise ölçeğe göre artan getiriye (Increasing) sahiptir. Yani bu bankalar bir birim girdiyle bir birimden daha fazla çıktı üretebilecekken kaynaklarını verimli kullanamamışlar ve daha az çıtı elde etmişlerdir. Bu bankalar gelişme potansiyellerini daha iyi kullanıp daha fazla çıktı üretebilirler.

Tablo 5. 2011 Yılı Süper Etkinlik Değerleri ve Sıralama

\begin{tabular}{|c|c|c|c|}
\hline \multicolumn{4}{|c|}{ Model = Super-BCC-I-2011 } \\
\hline Banka Etkinlik Sıralaması & Karar Verme Birimi & Banka Skorları & Banka No \\
\hline 1 & $\mathrm{~K}-2$ & 4.21839 & 2 \\
\hline 2 & $\mathrm{~K}-1$ & 1.70256 & 1 \\
\hline 3 & $\mathrm{~K}-3$ & 1.68707 & 3 \\
\hline 4 & M-6 & 1.60083 & 8 \\
\hline 5 & M-2 & 1.03826 & 4 \\
\hline 6 & M-9 & 1.03609 & 11 \\
\hline 7 & M-8 & 1.00085 & 10 \\
\hline
\end{tabular}

Tablo 5'de görüldügü gibi, 2011 yılında toplam etkin olan bankalar arasında süper etkinlik modeli kullanılarak bankaların etkinlik sıralaması yeniden belirlenmiştir. Buna göre, Super-BCC-I etkinlik değerlerine göre K-2 kodlu Kuveyt Türk Katılım Bankası A.Ș. en etkin banka olurken etkin bankalar içinde en az etkin olan banka ise M-8 Türkiye İş Bankası A.Ş.'dir. Etkin olmayan KVB'nin süper etkinlik değerleri ile görece etkinlik değerleri birbirine eşit olacağından, bunların etkinlik sıra numarası değişmeyecektir. 0 yüzden etkin olmayan birimler süper etkinliğe dahil edilmemiştir. 
Tablo 6. Bankaların 2012 Yılı BCC-I Değerleri ve Ölçek Getiri Türleri

\begin{tabular}{|c|c|c|c|c|}
\hline \multicolumn{5}{|c|}{ BCC (Teknik Etkinlik Değeri (2012) } \\
\hline KVB & $\begin{array}{c}\text { Etkinlik } \\
\text { Skoru }\end{array}$ & $\begin{array}{c}\text { Referans } \\
\text { Kümesi }\end{array}$ & $\begin{array}{c}\text { Etkinlik } \\
\text { Sirası }\end{array}$ & ölcek Getiri Türü \\
\hline Albaraka Türk Katılım Bankası A.Ș. & 1 & $\mathrm{~K}-1$ & 1 & Decreasing \\
\hline Kuveyt Türk Katılım Bankası A.Ş. & 1 & $\mathrm{~K}-2$ & 1 & Constant \\
\hline Türkiye Finans Katılım Bankası & & & & \\
\hline A.Ş. & 1 & $\mathrm{~K}-3$ & 1 & Constant \\
\hline Akbank T.A.S. & 1 & M-2 & 1 & Constant \\
\hline Anadolubank A.Ş. & 1 & $\mathrm{M}-3$ & 1 & Constant \\
\hline Fibabanka A.Ş. & 0.91622 & $\mathrm{~K}-1$ & 9 & Decreasing \\
\hline Șekerbank T.A.Ș. & 0.87082 & $\mathrm{~K}-2$ & 10 & Increasing \\
\hline Turkish Bank A.Ş. & 1 & M-6 & 1 & Increasing \\
\hline Türk Ekonomi Bankası A.Ş. & 0.80965 & $\mathrm{~K}-2$ & 11 & Increasing \\
\hline Türkiye İș Bankası A.Ș. & 1 & M-8 & 1 & Constant \\
\hline Yapı ve Kredi Bankası A.Ș. & 0.92717 & $\mathrm{~K}-2$ & 8 & Increasing \\
\hline
\end{tabular}

Tablo 6'da 2012 yılı BCC-I sonuçlarına göre Türkiye'deki Katılım Bankalarının ve Özel sermayeli mevduat bankalarının etkinlik skorları referans kümeleri, etkinlik sıraları ve ölçek getiri türleri gösterilmiştir.

Tabloya göre 2012 yılında, BCC-I yaklaşımına göre, analize dahil edilen 11 bankadan 7'si yeterli etkinlik skoruna ulaşırken, 4 banka (Fibabanka A.Ş, Şekerbank, Yapı ve Kredi Bankası A.Ş. ve Türk Ekonomi Bankası) yeterli etkinlik skoruna ulaşamamıştır.

Ölçek etkinlik türlerine bakıldığında 2011 yılında 2 banka ölçeğe göre azalan getiriye (Decreasing) sahip olduğu ve gelişme potansiyellerini yeterince kullanamadıkları görülmektedir. Bu bankalardan etkin kapasiteye ulaşabilmeleri için üretim yöntemlerini daha etkin etkin kullanmaları beklenir. 5 bankanın ölçek getiri türü ölçeğe göre sabit getirilidir (Constant) yani bu bankalar girdi kadar çıktı üretmektedir. Bu bankalar için ölçek etkinlik türüne göre herhangi bir azaltma ya da arttırmadan bahsedilemez. 4 banka ise ölçeğe göre artan getiriye (Increasing) sahiptir. Yani bu bankalar bir birim girdiyle bir birimden daha fazla çıktı üretebilecekken kaynaklarını verimli kullanamamışlar ve daha az çıktı elde etmişlerdir. Bu bankalar gelişme potansiyellerini daha iyi kullanıp daha fazla çıktı üretebilirler.

Tablo 7. 2012 Yılı Süper Etkinlik Değerleri ve Sıralama

\begin{tabular}{cccc}
\hline & \multicolumn{2}{c}{ Model $=$ Super-BCC-I-2012 } & \\
Banka Etkinlik Siralamasi & Karar Verme Birimi & Banka Skorları & Banka No \\
1 & K-1 & 1.54512 & 1 \\
2 & M-3 & 1.30241 & 5 \\
3 & K-2 & 1.23993 & 2 \\
4 & M-6 & 1.23581 & 8 \\
5 & K-3 & 1.10832 & 3 \\
6 & M-2 & 1.04739 & 4 \\
7 & M-8 & 1 & 10 \\
\hline
\end{tabular}

Tablo 7'de görüldüğü gibi, 2012 yılında toplam etkin olan bankalar arasında süper etkinlik modeli kullanılarak bankaların etkinlik sıralaması yeniden belirlenmiştir. Buna göre, Super-BCC-I etkinlik değerlerine göre K-1 kodlu Albaraka Türk Katılım Bankası A.Ş.. en etkin banka olurken etkin bankalar içinde en az etkin olan banka ise M-8 Türkiye İş Bankası A.Ş.'dir. Etkin olmayan KVB'nin süper etkinlik değerleri ile görece etkinlik değerleri birbirine eșit olacağından, bunların etkinlik sıra numarası değișmeyecektir. 0 yüzden etkin olmayan birimler süper etkinliğe dahil edilmemiștir. 
Tablo 8. Bankaların 2013 Yılı BCC-I Değerleri ve Ölçek Getiri Türleri

\begin{tabular}{|c|c|c|c|c|}
\hline \multicolumn{5}{|c|}{ BCC (Teknik Etkinlik Değeri (2013) } \\
\hline KVB & $\begin{array}{c}\text { Etkinlik } \\
\text { Skoru }\end{array}$ & $\begin{array}{c}\text { Referans } \\
\text { Kümesi }\end{array}$ & $\begin{array}{c}\text { Etkinlik } \\
\text { Sirası }\end{array}$ & Ölçek Getiri Türü \\
\hline Albaraka Türk Katılım Bankası A.Ș. & 1 & $\mathrm{~K}-1$ & 1 & Constant \\
\hline $\begin{array}{l}\text { Kuveyt Türk Katılım Bankası A.Ș. } \\
\text { Türkiye Finans Katılım Bankası }\end{array}$ & 1 & $\mathrm{~K}-2$ & 1 & Increasing \\
\hline A.Ș. & 0.97798 & $\mathrm{~K}-1$ & 7 & Increasing \\
\hline Akbank T.A.Ş. & 0.99589 & M-6 & 6 & Increasing \\
\hline Anadolubank A.Ş. & 0.87787 & $\mathrm{~K}-2$ & 9 & Increasing \\
\hline Fibabanka A.Ş. & 1 & M-4 & 1 & Increasing \\
\hline Şekerbank T.A.Ş. & 0.8429 & $\mathrm{~K}-2$ & 10 & Increasing \\
\hline Turkish Bank A.Ș. & 1 & M-6 & 1 & Increasing \\
\hline Türk Ekonomi Bankası A.Ș. & 0.8191 & $\mathrm{~K}-2$ & 11 & Increasing \\
\hline Türkiye İș Bankası A.Ș. & 0.93234 & M-6 & 8 & Increasing \\
\hline Yapı ve Kredi Bankası A.Ș. & 1 & M-9 & 1 & Constant \\
\hline
\end{tabular}

Tablo 8'de 2013 yılı BCC-I sonuçlarına göre Türkiye'deki Katılım Bankalarının ve Özel sermayeli mevduat bankalarının etkinlik skorları referans kümeleri, etkinlik sıraları ve ölçek getiri türleri gösterilmiştir.

Tabloya göre 2013 yılında, BCC-I yaklaşımına göre, analize dahil edilen 11 bankadan 5'i yeterli etkinlik skoruna ulaşırken, 6 banka (Türkiye Finans Katılım Bankası A.Ş, Akbank T.A.Ș, Anadolubank A.Ş, Şekerbank, Yapı ve Kredi Bankası A.Ş. ve Türk Ekonomi Bankası) yeterli etkinlik skoruna ulaşamamıștır.

Ölçek etkinlik türlerine bakıldığında 2011 yılında hiçbir bankanın ölçeğe göre azalan getiriye (Decreasing) sahip olmadığı görülmektedir. Bu bankalardan etkin kapasiteye ulaşabilmeleri için üretim yöntemlerini daha etkin etkin kullanmaları beklenir. 2 bankanın ölçek getiri türü ölçeğe göre sabit getirilidir (Constant) yani bu bankalar girdi kadar çıktı üretmektedir. Bu bankalar için ölçek etkinlik türüne göre herhangi bir azaltma ya da arttırmadan bahsedilemez. 9 banka ise ölçeğe göre artan getiriye (Increasing) sahiptir. Yani bu bankalar bir birim girdiyle bir birimden daha fazla çıktı üretebilecekken kaynaklarını verimli kullanamamışlar ve daha az çıktı elde etmişlerdir. Bu bankalar gelişme potansiyellerini daha iyi kullanıp daha fazla çıktı üretebilirler.

Tablo 9. 2013 Yılı Süper Etkinlik Değerleri ve Sıralama

\begin{tabular}{cccc}
\hline \multicolumn{4}{c}{ Model = Super-BCC-I-2013 } \\
\hline Banka Etkinlik Siralaması & Karar Verme Birimi & Banka Skorları & Banka No \\
\hline 1 & K-1 & 1.52162 & 1 \\
2 & M-4 & 1.45834 & 6 \\
3 & M-6 & 1.15399 & 8 \\
4 & K-2 & 1.07329 & 2 \\
5 & M-9 & 1.06791 & 11 \\
\hline
\end{tabular}

Tablo 9'da görüldüğü gibi, 2013 yılında toplam etkin olan bankalar arasında süper etkinlik modeli kullanılarak bankaların etkinlik sıralaması yeniden belirlenmiștir. Buna göre, Super-BCC-I etkinlik değerlerine göre K-1 kodlu Albaraka Türk Katılım Bankası A.Ş.. en etkin banka olurken etkin bankalar içinde en az etkin olan banka ise M-9 Yapı ve Kredi Bankası A.Ş.'dir. Etkin olmayan KVB'nin süper etkinlik değerleri ile görece etkinlik değerleri birbirine eşit olacağından, bunların etkinlik sıra numarası değişmeyecektir. 0 yüzden etkin olmayan birimler süper etkinliğe dahil edilmemiştir. 
Tablo 10. Bankaların 2014 Yılı BCC-I Değerleri ve Ölçek Getiri Türleri

\begin{tabular}{lcccc}
\hline \multicolumn{1}{c}{ KVB } & BCC (Teknik Etkinlik Değeri (2014) & & \\
\hline & $\begin{array}{c}\text { Etkinlik } \\
\text { Skoru }\end{array}$ & $\begin{array}{c}\text { Referans } \\
\text { Kümesi }\end{array}$ & $\begin{array}{c}\text { Etkinlik } \\
\text { Sırası }\end{array}$ & Ölçek Getiri Türü \\
\hline Albaraka Türk Katılım Bankası A.Ş. & 1 & K-1 & 1 & Constant \\
Kuveyt Türk Katılım Bankası A.Ș. & 1 & K-2 & 1 & Increasing \\
\hline Türkiye Finans Katılım Bankası & & & & \\
A.SS. & 0.87898 & K-2 & 9 & Increasing \\
Akbank T.A.Ş. & 1 & M-2 & 1 & Constant \\
Anadolubank A.Ş. & 1 & M-3 & 1 & Constant \\
Fibabanka A.Ş. & 1 & M-4 & 1 & Constant \\
Şekerbank T.A.Ş. & 0.87692 & K-2 & 10 & Increasing \\
Turkish Bank A.S.S. & 1 & M-6 & 1 & Increasing \\
Türk Ekonomi Bankası A.Ş. & 0.83957 & K-2 & 11 & Increasing \\
Türkiye İș Bankası A.Ş. & 0.95081 & K-2 & 7 & Increasing \\
Yapı ve Kredi Bankası A.Ș. & 0.89948 & K-2 & 8 & Increasing \\
\hline
\end{tabular}

Tablo 10'da 2014 yılı BCC-I sonuçlarına göre Türkiye'deki Katılım Bankalarının ve Özel sermayeli mevduat bankalarının etkinlik skorları referans kümeleri, etkinlik sıraları ve ölçek getiri türleri gösterilmiştir.

Tabloya göre 2014 yılında, BCC-I yaklaşımına göre, analize dahil edilen 11 bankadan 6'sı yeterli etkinlik skoruna ulaşırken, 5 banka (Türkiye Finans Katılım Bankası A.Ş, Şekerbank, Yapı ve Kredi Bankası A.Ş. ve Türk Ekonomi Bankası, Türkiye İş Bankası A.Ş.) yeterli etkinlik skoruna ulaşamamıştır.

Ölçek etkinlik türlerine bakıldığında 2011 yılında hiçbir bankanın ölçeğe göre azalan getiriye (Decreasing) sahip olmadığı görülmektedir. Bu bankalardan etkin kapasiteye ulaşabilmeleri için üretim yöntemlerini daha etkin etkin kullanmaları beklenir. 4 bankanın ölçek getiri türü ölçeğe göre sabit getirilidir (Constant) yani bu bankalar girdi kadar çıktı üretmektedir. Bu bankalar için ölçek etkinlik türüne göre herhangi bir azaltma ya da arttırmadan bahsedilemez. 7 banka ise ölçeğe göre artan getiriye (Increasing) sahiptir. Yani bu bankalar bir birim girdiyle bir birimden daha fazla çıktı üretebilecekken kaynaklarını verimli kullanamamışlar ve daha az çıktı elde etmişlerdir. Bu bankalar gelişme potansiyellerini daha iyi kullanıp daha fazla çıktı üretebilirler.

Tablo 11. 2014 Yılı Süper Etkinlik Değerleri ve Sıralama

\begin{tabular}{cccc}
\hline & \multicolumn{2}{c}{ Model = Super-BCC-I-2014 } \\
\hline Banka Etkinlik Siralaması & Karar Verme Birimi & Banka Skorları & Banka No \\
\hline $\mathbf{1}$ & $\mathrm{M}-3$ & 1.65093 & 5 \\
$\mathbf{2}$ & $\mathrm{K}-1$ & 1.17181 & 1 \\
$\mathbf{3}$ & $\mathrm{M}-4$ & 1.13846 & 6 \\
$\mathbf{4}$ & $\mathrm{M}-6$ & 1.08061 & 2 \\
$\mathbf{5}$ & $\mathrm{K}-2$ & 1.05155 & 4 \\
$\mathbf{6}$ & $\mathrm{M}-2$ & 1.03456 & 4 \\
\hline
\end{tabular}

Tablo 11'de görüldüğü gibi, 2014 yılında toplam etkin olan bankalar arasında süper etkinlik modeli kullanılarak bankaların etkinlik sıralaması yeniden belirlenmiştir. Buna göre, Super-BCC-I etkinlik değerlerine göre M-3 kodlu Anadolubank A.Ş. en etkin banka olurken etkin bankalar içinde en az etkin olan banka ise M-2 Akbank T.A.Ş.'dir. Etkin olmayan KVB'nin süper etkinlik değerleri ile görece etkinlik değerleri birbirine eșit olacağından, bunların etkinlik sıra numarası değişmeyecektir. 0 yüzden etkin olmayan birimler süper etkinliğe dahil edilmemiștir. 
Tablo 12. Bankaların 2015 Yılı BCC-I Değerleri ve Ölçek Getiri Türleri

\begin{tabular}{lcccc}
\hline \multicolumn{1}{c}{ KVB } & $\begin{array}{c}\text { Etkinlik } \\
\text { Skoru }\end{array}$ & $\begin{array}{c}\text { Referans } \\
\text { Kümesi }\end{array}$ & $\begin{array}{c}\text { Etkinlik } \\
\text { Sırası }\end{array}$ & Ölçek Getiri Türü \\
\hline Albaraka Türk Katılım Bankası A.Ş. & 1 & K-1 & 1 & Constant \\
Kuveyt Türk Katılım Bankası A.S.. & 1 & K-2 & 1 & Constant \\
Türkiye Finans Katılım Bankası & & & & \\
A.SS. & 0.87644 & K-2 & 10 & Increasing \\
Akbank T.A.Ş. & 1 & M-2 & 1 & Constant \\
Anadolubank A.Ş. & 1 & M-3 & 1 & Constant \\
Fibabanka A.Ş. & 0.86647 & K-2 & 11 & Increasing \\
Şekerbank T.A.S. & 0.89216 & K-2 & 9 & Increasing \\
Turkish Bank A.Ş. & 1 & M-6 & 1 & Increasing \\
Türk Ekonomi Bankası A.Ş. & 1 & M-7 & 1 & Constant \\
Türkiye İș Bankası A.Ş. & 0.94302 & K-2 & 7 & Increasing \\
Yapı ve Kredi Bankası A.Ș. & 0.90385 & K-2 & 8 & Increasing \\
\hline
\end{tabular}

Tablo 12'de 2015 yılı BCC-I sonuçlarına göre Türkiye'deki Katılım Bankalarının ve Özel sermayeli mevduat bankalarının etkinlik skorları referans kümeleri, etkinlik sıraları ve ölçek getiri türleri gösterilmiştir.

Tabloya göre 2015 yılında, BCC-I yaklaşımına göre, analize dahil edilen 11 bankadan 6'sı yeterli etkinlik skoruna ulaşırken, 5 banka (Türkiye Finans Katılım Bankası A.Ş, Fibabanka A.Ş, Şekerbank, Yapı ve Kredi Bankası A.Ş ve Türkiye İş Bankası A.Ş.) yeterli etkinlik skoruna ulaşamamıştır.

Ölçek etkinlik türlerine bakıldığında 2011 yılında hiçbir bankanın ölçeğe göre azalan getiriye (Decreasing) sahip olmadığı görülmektedir. Bu bankalardan etkin kapasiteye ulaşabilmeleri için üretim yöntemlerini daha etkin etkin kullanmaları beklenir. 5 bankanın ölçek getiri türü ölçeğe göre sabit getirilidir (Constant) yani bu bankalar girdi kadar çıtı üretmektedir. Bu bankalar için ölçek etkinlik türüne göre herhangi bir azaltma ya da arttırmadan bahsedilemez. 6 banka ise ölçeğe göre artan getiriye (Increasing) sahiptir. Yani bu bankalar bir birim girdiyle bir birimden daha fazla çıktı üretebilecekken kaynaklarını verimli kullanamamışlar ve daha az çıktı elde etmişlerdir. Bu bankalar gelişme potansiyellerini daha iyi kullanıp daha fazla çıktı üretebilirler.

Tablo 13. 2015 Yılı Süper Etkinlik Değerleri ve Sıralama

\begin{tabular}{cccc}
\hline & \multicolumn{2}{c}{ Model = Super-BCC-I-2015 } \\
\hline Banka Etkinlik Siralaması & Karar Verme Birimi & Banka Skorları & Banka No \\
\hline 1 & M-7 & 1.31624 & 9 \\
2 & M-3 & 1.27947 & 5 \\
3 & K-1 & 1.17379 & 1 \\
4 & K-2 & 1.06959 & 2 \\
5 & M-6 & 1.06471 & 8 \\
6 & M-2 & 1.01908 & 4 \\
\hline
\end{tabular}

Tablo 13'de görüldüğü gibi, 2015 yılında toplam etkin olan bankalar arasında süper etkinlik modeli kullanılarak bankaların etkinlik sıralaması yeniden belirlenmiştir. Buna göre, Super-BCC-I etkinlik değerlerine göre M-7kodlu Türk Ekonomi Bankası A.Ş. en etkin banka olurken etkin bankalar içinde en az etkin olan banka ise M-2 Akbank T.A.Ş.'dir. Etkin olmayan KVB'nin süper etkinlik değerleri ile görece etkinlik değerleri birbirine eşit olacağından, bunların etkinlik sıra numarası değişmeyecektir. 0 yüzden etkin olmayan birimler süper etkinliğe dahil edilmemiştir. 
Tablo 14. Bankaların 2016 Yılı BCC-I Değerleri ve Ölçek Getiri Türleri

\begin{tabular}{|c|c|c|c|c|}
\hline \multicolumn{5}{|c|}{ BCC (Teknik Etkinlik Değeri (2016) } \\
\hline KVB & $\begin{array}{l}\text { Etkinlik } \\
\text { Skoru }\end{array}$ & $\begin{array}{c}\text { Referans } \\
\text { Kümesi }\end{array}$ & $\begin{array}{l}\text { Etkinlik } \\
\text { Sirası }\end{array}$ & Ölçek Getiri Türü \\
\hline Albaraka Türk Katılım Bankası A.Ș. & 0.94959 & $\mathrm{~K}-2$ & 6 & Increasing \\
\hline $\begin{array}{l}\text { Kuveyt Türk Katılım Bankası A.Ş. } \\
\text { Türkiye Finans Katılım Bankası }\end{array}$ & 1 & $\mathrm{~K}-2$ & 1 & Constant \\
\hline A.Ş. & 0.88857 & $\mathrm{~K}-2$ & 8 & Constant \\
\hline Akbank T.A.Ş. & 1 & M-2 & 1 & Constant \\
\hline Anadolubank A.Ş. & 1 & $M-3$ & 1 & Constant \\
\hline Fibabanka A.Ş. & 0.80439 & $\mathrm{~K}-2$ & 10 & Increasing \\
\hline Şekerbank T.A.Ş. & 0.79293 & $\mathrm{~K}-2$ & 11 & Constant \\
\hline Turkish Bank A.Ş. & 1 & M-6 & 1 & Increasing \\
\hline Türk Ekonomi Bankası A.Ş. & 0.99195 & $\mathrm{~K}-2$ & 5 & Increasing \\
\hline Türkiye İş Bankası A.Ş. & 0.94225 & $\mathrm{~K}-2$ & 7 & Constant \\
\hline Yapı ve Kredi Bankası A.Ș. & 0.86145 & $\mathrm{~K}-2$ & 9 & Constant \\
\hline
\end{tabular}

Tablo 14'de 2016 yılı BCC-I sonuçlarına göre Türkiye'deki Katılım Bankalarının ve Özel sermayeli mevduat bankalarının etkinlik skorları referans kümeleri, etkinlik sıraları ve ölçek getiri türleri gösterilmiştir.

Tabloya göre 2016 yılında, BCC-I yaklaşımına göre, analize dahil edilen 11 bankadan 4'ü yeterli etkinlik skoruna ulaşırken, 7 banka (Albaraka Türk Katılım Bankası A.Ş, Türkiye Finans Katılım Bankası A.Ş, Fibabanka A.Ș, Șekerbank, Türk Ekonomi Bankası A.Ş, Yapı ve Kredi Bankası A.Ş ve Türkiye İş Bankası A.Ş.) yeterli etkinlik skoruna ulaşamamıştır.

Ölçek etkinlik türlerine bakıldığında 2011 yılında hiçbir bankanın ölçeğe göre azalan getiriye (Decreasing) sahip olmadığı görülmektedir. Bu bankalardan etkin kapasiteye ulaşabilmeleri için üretim yöntemlerini daha etkin etkin kullanmaları beklenir. 7 bankanın ölçek getiri türü ölçeğe göre sabit getirilidir (Constant) yani bu bankalar girdi kadar çıktı üretmektedir. Bu bankalar için ölçek etkinlik türüne göre herhangi bir azaltma ya da arttırmadan bahsedilemez. 4 banka ise ölçeğe göre artan getiriye (Increasing) sahiptir. Yani bu bankalar bir birim girdiyle bir birimden daha fazla çıktı üretebilecekken kaynaklarını verimli kullanamamışlar ve daha az çıktı elde etmişlerdir. Bu bankalar gelişme potansiyellerini daha iyi kullanıp daha fazla çıktı üretebilirler.

Tablo 15. 2016 Yılı Süper Etkinlik Değerleri ve Sıralama

\begin{tabular}{cccc}
\hline \multicolumn{4}{c}{ Model = Super-BCC-I-2016 } \\
\hline Banka Etkinlik Siralaması & Karar Verme Birimi & Banka Skorları & Banka No \\
\hline 1 & M-3 & 1.4907 & 5 \\
2 & M-6 & 1.46113 & 8 \\
3 & K-2 & 1.38176 & 2 \\
4 & M-2 & 1.04885 & 4 \\
\hline
\end{tabular}

Tablo 15'de görüldüğü gibi, 2016 yılında toplam etkin olan bankalar arasında süper etkinlik modeli kullanılarak bankaların etkinlik sıralaması yeniden belirlenmiştir. Buna göre, Super-BCC-I etkinlik değerlerine göre M-3 kodlu Anadolubank A.Ș. en etkin banka olurken etkin bankalar içinde en az etkin olan banka ise M-2 Akbank T.A.Ş.'dir. Etkin olmayan KVB'nin süper etkinlik değerleri ile görece etkinlik değerleri birbirine eșit olacağından, bunların etkinlik sıra numarası değişmeyecektir. 0 yüzden etkin olmayan birimler süper etkinliğe dahil edilmemiștir. 
Tablo 16. Bankaların 2017 Yılı BCC-I Değerleri ve Ölçek Getiri Türleri

\begin{tabular}{|c|c|c|c|c|}
\hline \multicolumn{5}{|c|}{ BCC (Teknik Etkinlik Değeri (2017) } \\
\hline KVB & $\begin{array}{l}\text { Etkinlik } \\
\text { Skoru }\end{array}$ & $\begin{array}{l}\text { Referans } \\
\text { Kümesi }\end{array}$ & $\begin{array}{l}\text { Etkinlik } \\
\text { Sirası }\end{array}$ & Ölçek Getiri Türü \\
\hline Albaraka Türk Katılım Bankası A.Ș. & 0.9526 & $\mathrm{~K}-2$ & 8 & Constant \\
\hline $\begin{array}{l}\text { Kuveyt Türk Katılım Bankası A.Ş. } \\
\text { Türkiye Finans Katılım Bankası }\end{array}$ & 1 & $\mathrm{~K}-2$ & 1 & Constant \\
\hline A.Ş. & 0.96344 & $\mathrm{~K}-2$ & 6 & Constant \\
\hline Akbank T.A.Ş. & 1 & M-2 & 1 & Constant \\
\hline Anadolubank A.Ş. & 1 & M-3 & 1 & Constant \\
\hline Fibabanka A.Ș. & 0.87296 & $\mathrm{~K}-2$ & 11 & Constant \\
\hline Șekerbank T.A.Ș. & 0.95484 & $\mathrm{~K}-2$ & 7 & Constant \\
\hline Turkish Bank A.Ș. & 1 & M-6 & 1 & Constant \\
\hline Türk Ekonomi Bankası A.Ș. & 1 & M-7 & 1 & Constant \\
\hline Türkiye İș Bankası A.Ș. & 0.92997 & $\mathrm{~K}-2$ & 10 & Constant \\
\hline Yapı ve Kredi Bankası A.S. & 0.94637 & $\mathrm{~K}-2$ & 9 & Constant \\
\hline
\end{tabular}

Tablo 16'da 2017 yılı BCC-I sonuçlarına göre Türkiye'deki Katılım Bankalarının ve Özel sermayeli mevduat bankalarının etkinlik skorları referans kümeleri, etkinlik sıraları ve ölçek getiri türleri gösterilmiştir.

Tabloya göre 2017 yılında, BCC-I yaklaşımına göre, analize dahil edilen 11 bankadan 5'i yeterli etkinlik skoruna ulașırken, 6 banka (Albaraka Türk Katılım Bankası A.Ș, Türkiye Finans Katılım Bankası A.Ș, Fibabanka A.Ş, Şekerbank, Yapı ve Kredi Bankası A.Ş ve Türkiye İş Bankası A.Ş.) yeterli etkinlik skoruna ulaşamamıștır.

Ölçek etkinlik türlerine bakıldığında 2011 yılında hiçbir bankanın ölçeğe göre azalan getiriye (Decreasing) sahip olmadığı görülmektedir. Bu bankalardan etkin kapasiteye ulaşabilmeleri için üretim yöntemlerini daha etkin etkin kullanmaları beklenir. Bu yılda tüm bankaların ölçek getiri türü ölçeğe göre sabit getirilidir (Constant) yani bu bankalar girdi kadar çıktı üretmektedir. Bu bankalar için ölçek etkinlik türüne göre herhangi bir azaltma ya da arttırmadan bahsedilemez.

Tablo 17. 2017 Yılı Süper Etkinlik Değerleri ve Sıralama

\begin{tabular}{cccc}
\hline & \multicolumn{2}{c}{ Model = Super-BCC-I-2017 } & \\
\hline Banka Etkinlik Siralaması & Karar Verme Birimi & Banka Skorları & Banka No \\
\hline 1 & M-6 & 6.79835 & 8 \\
2 & K-2 & 1.40516 & 2 \\
3 & M-7 & 1.29689 & 5 \\
4 & M-3 & 1.09609 & 4 \\
5 & M-2 & 1.04975 & 5 \\
\hline
\end{tabular}

Tablo 17'de görüldüğü gibi, 2017 yılında toplam etkin olan bankalar arasında süper etkinlik modeli kullanılarak bankaların etkinlik sıralaması yeniden belirlenmiștir. Buna göre, Super-BCC-I etkinlik değerlerine göre M-6 kodlu Turkish Bank A.Ș. en etkin banka olurken etkin bankalar içinde en az etkin olan banka ise M-2 Akbank T.A.Ş.'dir. Etkin olmayan KVB'nin süper etkinlik değerleri ile görece etkinlik değerleri birbirine eșit olacağından, bunların etkinlik sıra numarası değişmeyecektir. 0 yüzden etkin olmayan birimler süper etkinliğe dahil edilmemiştir. 
Tablo 18. Bankaların 2018 Yılı BCC-I Değerleri ve Ölçek Getiri Türleri

\begin{tabular}{|c|c|c|c|c|}
\hline \multicolumn{5}{|c|}{ BCC (Teknik Etkinlik Değeri (2018) } \\
\hline KVB & $\begin{array}{c}\text { Etkinlik } \\
\text { Skoru }\end{array}$ & $\begin{array}{c}\text { Referans } \\
\text { Kümesi }\end{array}$ & $\begin{array}{c}\text { Etkinlik } \\
\text { Sirası }\end{array}$ & Ölçek Getiri Türü \\
\hline Albaraka Türk Katılım Bankası A.Ș. & 0.97365 & $\mathrm{M}-2$ & 9 & Increasing \\
\hline $\begin{array}{l}\text { Kuveyt Türk Katılım Bankası A.Ş. } \\
\text { Türkiye Finans Katılım Bankası }\end{array}$ & 1 & $\mathrm{~K}-2$ & 1 & Constant \\
\hline A.Ş. & 0.99118 & M-3 & 6 & Increasing \\
\hline Akbank T.A.Ș. & 1 & M-2 & 1 & Constant \\
\hline Anadolubank A.Ș. & 1 & M-3 & 1 & Constant \\
\hline Fibabanka A.Ş. & 0.94549 & M-3 & 11 & Increasing \\
\hline Șekerbank T.A.Ș. & 0.98981 & M-3 & 7 & Increasing \\
\hline Turkish Bank A.Ș. & 0.97539 & M-2 & 8 & Increasing \\
\hline Türk Ekonomi Bankası A.Ş. & 0.94919 & M-3 & 10 & Increasing \\
\hline Türkiye İș Bankası A.Ş. & 1 & M-8 & 1 & Increasing \\
\hline Yapı ve Kredi Bankası A.Ș. & 0.99206 & $\mathrm{M}-2$ & 5 & Increasing \\
\hline
\end{tabular}

Tablo 18'de 2018 yılı BCC-I sonuçlarına göre Türkiye'deki Katılım Bankalarının ve Özel sermayeli mevduat bankalarının etkinlik skorları referans kümeleri, etkinlik sıraları ve ölçek getiri türleri gösterilmiştir.

Tabloya göre 2018 yılında, BCC-I yaklaşımına göre, analize dahil edilen 11 bankadan 4'ü yeterli etkinlik skoruna ulaşırken, 7 banka (Kuveyt Türk Katılım Bankası A.Ş., Türkiye Finans Katılım Bankası A.Ş, Fibabanka A.Ş, Şekerbank, Turkish Bank A.Ş, Türk Ekonomi Bankası A.Ş, Yapı ve Kredi Bankası A.Ş ) yeterli etkinlik skoruna ulaşamamıştır.

Ölçek etkinlik türlerine bakıldığında 2011 yılında hiçbir bankanın ölçeğe göre azalan getiriye (Decreasing) sahip olmadığı görülmektedir. Bu bankalardan etkin kapasiteye ulaşabilmeleri için üretim yöntemlerini daha etkin etkin kullanmaları beklenir. 3 bankanın ölçek getiri türü ölçeğe göre sabit getirilidir (Constant) yani bu bankalar girdi kadar çıktı üretmektedir. Bu bankalar için ölçek etkinlik türüne göre herhangi bir azaltma ya da arttırmadan bahsedilemez. 8 banka ise ölçeğe göre artan getiriye (Increasing) sahiptir. Yani bu bankalar bir birim girdiyle bir birimden daha fazla çıktı üretebilecekken kaynaklarını verimli kullanamamışlar ve daha az çıktı elde etmişlerdir. Bu bankalar gelişme potansiyellerini daha iyi kullanıp daha fazla çıktı üretebilirler.

Tablo 19. 2018 Yılı Süper Etkinlik Değerleri ve Sıralama

\begin{tabular}{cccc}
\hline & \multicolumn{2}{c}{ Model = Super-BCC-I-2018 } \\
\hline Banka Etkinlik Siralaması & Karar Verme Birimi & Banka Skorları & Banka No \\
1 & $\mathrm{M}-3$ & 1.19368 & 5 \\
2 & $\mathrm{M}-2$ & 1.05298 & 4 \\
3 & $\mathrm{M}-8$ & 1.00221 & 10 \\
4 & $\mathrm{~K}-2$ & 1 & 2 \\
\hline
\end{tabular}

Tablo 19'da görüldüğü gibi, 2018 yılında toplam etkin olan bankalar arasında süper etkinlik modeli kullanılarak bankaların etkinlik sıralaması yeniden belirlenmiștir. Buna göre, Super-BCC-I etkinlik değerlerine göre M-3 kodlu Anadolubank A.Ş. en etkin banka olurken etkin bankalar içinde en az etkin olan banka ise k-2 Kuveyt Türk Katılım Bankası A.Ş'dir. Etkin olmayan KVB'nin süper etkinlik değerleri ile görece etkinlik değerleri birbirine eşit olacağından, bunların etkinlik sıra numarası değişmeyecektir. 0 yüzden etkin olmayan birimler süper etkinliğe dahil edilmemiştir. 
Tablo 20. 2015-2018 yılları arası Malmquist I-V Index

\begin{tabular}{ccccc}
\hline Malmquist & $\mathbf{2 0 1 5}=>\mathbf{2 0 1 6}$ & $\mathbf{2 0 1 6}=>\mathbf{2 0 1 7}$ & $\mathbf{2 0 1 7}=>\mathbf{2 0 1 8}$ & Average \\
\hline K-1 & 0.772309 & 0.889484 & 0.644361 & $\mathbf{0 . 8 9 7 8 2 5}$ \\
K-2 & 1.085056 & 1.14212 & 0.539696 & $\mathbf{0 . 7 7 2 6 0 9}$ \\
K-3 & 0.944907 & 1.016644 & 0.735015 & $\mathbf{0 . 8 3 9 5 9 8}$ \\
M-2 & 1.143164 & 0.997557 & 1.045144 & $\mathbf{0 . 9 6 4 2 8 1}$ \\
M-3 & 1.267218 & 0.775051 & 0.61958 & $\mathbf{0 . 9 5 4 9 4 6}$ \\
M-5 & 0.996125 & 1.277318 & 0.654202 & $\mathbf{0 . 9 7 2 6 1 1}$ \\
M-6 & 1.394741 & 3.450417 & 0.081221 & $\mathbf{1 . 2 1 0 4 4 2}$ \\
M-7 & 0.88429 & 1.027122 & 0.516349 & $\mathbf{0 . 9 4 2 8 1 2}$ \\
M-8 & 1.305236 & 0.988575 & 0.864068 & $\mathbf{0 . 9 2 4 6 2 8}$ \\
M-9 & 1.152598 & 1.021061 & 0.868464 & $\mathbf{0 . 9 6 6 0 6 6}$ \\
Average & $\mathbf{1 . 0 9 4 5 6 4}$ & $\mathbf{1 . 2 5 8 5 3 5}$ & $\mathbf{0 . 6 5 6 8 1}$ & $\mathbf{0 . 9 4 4 5 8 2}$ \\
Max & 1.394741 & 3.450417 & 1.045144 & $\mathbf{1 . 2 1 0 4 4 2}$ \\
Min & 0.772309 & 0.775051 & 0.081221 & $\mathbf{0 . 7 7 2 6 0 9}$ \\
SD & 0.197279 & 0.781569 & 0.260548 & $\mathbf{0 . 1 1 3 3 3 7}$ \\
\hline
\end{tabular}

Tablo 20' de analize dahil edilen bankaların yıllar itibariyle toplam faktör endeks değerlerindeki değişmeler gösterilmiştir. Tabloya göre 2015 yılından 2016 yılına geçişte analize dahil edilen 10 bankanın ortalama değeri (1.09) çıkmış ve bankalar ortalama değer olarak toplam faktör verimliliğini aşmıştır. 2016-2017 yılları arasında bu değer (1.25) çlkmıștır. Değer 1'in üzerinde olduğu için bankaların bu dönemde de ortalama değer bazında faktör verimliliğini yakaladığı görülmektedir. 2017 yılından 2018 yılında geçişte bankaların ortalama faktör verimliliğinde (0.65) ciddi bir düşüş olduğu görülmektedir. Bu dönemde sadece bir banka faktör etkinliğini yakalarken diğer bankaların faktör etkin olmadıkları görülmektedir.

\section{SONUÇ VE ÖNERILER}

Türkiye'deki Özel Sermayeli Mevduat Bankalarının ve Katılım Bankalarının 2010-2018 yılları arası etkinlik sonuçlarının VZA, Süper Etkinlik ve Malmquist TFVE kullanılarak yapılan analizi sonucunda;

2010 yılında BCC-I yaklaşımında incelenen 3 katılım bankasından 2'si etkin çıkarken, 7 özel sermayeli mevduat bankasından 5'i yeterli etkinlik değerine ulaşmıştır. Bu yılda analize dâhil edilen bankalardan büyük çoğunluğunun (\%70) girdi değişkenlerini etkin kullandığı görülmektedir.

2010 yılında süper etkinlik sonuçlarına göre en etkin banka, Kuveyt Türk Katılım Bankası A.Ş olmuştur. Etkin çalışan bankalar içinde en az etkin bulunan banka ise Yapı ve Kredi Bankası A.Ş'dir.

2010 yılı ölçek getiri türleri incelendiğinde katılım bankalarından 2'si sabit getiri altından çalışmaktayken 1'inin ölçeğe göre artan getiriye sahip olduğu görülmektedir. Özel sermayeli mevduat bankalarından ise 4'ünün sabit getiriye, 3'ünün ise artan getiriye sahip oldukları görülmektedir.

2011 yılında BCC-I yaklaşımında 3 katılım bankasının tamamı etkin çıkarken, 8 özel sermayeli mevduat bankasından 4'ü yeterli etkinlik değerine ulaşmıştır. Bu yılda analize dâhil edilen bankaların çoğunluğunun (\%64) yeterli etkinlik skoruna ulaştıkları ve girdilerini etkin kullandıkları görülmektedir.

2011 yılında süper etkinlik sonuçlarına göre en etkin banka, Kuveyt Türk Katılım Bankası A.Ş olmuştur. Etkin çalışan bankalar içinde en az etkin bulunan banka ise Türkiye İş Bankası A.Ş.'dir.

2011 yılı ölçek getiri türleri incelendiğinde katılım bankalarından 3'ü de sabit getiri altından çalışmaktayken, Özel sermayeli mevduat bankalarından ise 3'ünün sabit getiriye, 5'inin ise artan getiriye sahip oldukları görülmektedir.

2012 yılında BCC-I yaklaşımında 3 katılım bankasının tamamı etkin çıkarken, 8 özel sermayeli mevduat bankasından 4'ü yeterli etkinlik değerine ulaşmıştır. Bu yılda analize dahil edilen bankaların çoğunluğunun (\%64) yeterli etkinlik skoruna ulaştıkları ve girdilerini etkin kullandıkları görülmektedir. 
2012 yılında süper etkinlik sonuçlarına göre en etkin banka, Albaraka Türk Katılım Bankası A.Ş olmuştur. Etkin çalışan bankalar içinde en az etkin bulunan banka ise Türkiye İş Bankası A.Ş.'dir.

2012 yılı ölçek getiri türleri incelendiğinde katılım bankalarından 1'inin azalan getiriye sahip olduğu diğer ikisinin ise sabit getiri altında çalıştığı görülmektedir. Özel sermayeli mevduat bankalarından ise 1 'i azalan getiriye sahipken, 3'ünün sabit getiriye, 4'ünün ise artan getiriye sahip oldukları görülmektedir.

2013 yılında BCC-I yaklaşımında incelenen 3 katılım bankasından 2'si etkin çıkarken, 8 özel sermayeli mevduat bankasından 3'ü yeterli etkinlik değerine ulaşmıştır. $\mathrm{Bu}$ yılda analize dahil edilen bankalardan çoğunluğunun (\%55) yeterli etkinlik skoruna ulaşamadıkları görülmektedir.

2013 yılında süper etkinlik sonuçlarına göre en etkin banka, Albaraka Türk Katılım Bankası A.Ş olmuştur. Etkin çalışan bankalar içinde en az etkin bulunan banka ise Yapı ve Kredi Bankası A.Ş.'dir.

2013 yılı ölçek getiri türleri incelendiğinde katılım bankalarından 1'inin sabit getiriye sahip olduğu diğer ikisinin ise artan getiri altında çalıştığı görülmektedir. Özel sermayeli mevduat bankalarından ise 1'i sabit getiriye sahipken, 3'ünün sabit getiriye, 7'sinin ise artan getiriye sahip oldukları görülmektedir.

2014 yılında BCC-I yaklaşımında incelenen 3 katılım bankasından 2'si etkin çıkarken, 8 özel sermayeli mevduat bankasından 4'ü yeterli etkinlik değerine ulaşmıștır. $\mathrm{Bu}$ yılda analize dahil edilen bankalardan çoğunluğunun (\%55) yeterli etkinlik skoruna ulaştıkları görülmektedir.

2014 yılında süper etkinlik sonuçlarına göre en etkin banka, Anadolubank A.Ş. olmuştur. Etkin çalışan bankalar içinde en az etkin bulunan banka ise Akbank T.A.Ş.'dir.

2014 yılı ölçek getiri türleri incelendiğinde katılım bankalarından 1'inin sabit getiriye sahip olduğu diğer ikisinin ise artan getiri altında çalıştığı görülmektedir. Özel sermayeli mevduat bankalarından ise 3'ü sabit getiriye sahipken, 5'inin ise artan getiriye sahip oldukları görülmektedir.

2015 yılında BCC-I yaklaşımında incelenen 3 katılım bankasından 2'si etkin çıkarken, 8 özel sermayeli mevduat bankasından 4'ü yeterli etkinlik değerine ulaşmıștır. $\mathrm{Bu}$ yılda analize dahil edilen bankalardan çoğunluğunun (\%55) yeterli etkinlik skoruna ulaştıkları görülmektedir.

2015 yılında süper etkinlik sonuçlarına göre en etkin banka Türk Ekonomi Bankası A.Ş.. olmuştur. Etkin çalışan bankalar içinde en az etkin bulunan banka ise Akbank T.A.Ş.'dir.

2015 yılı ölçek getiri türleri incelendiğinde katılım bankalarından 2'inin sabit getiriye sahip olduğu diğer birinin ise artan getiri altında çalıştı̆̆ görülmektedir. Özel sermayeli mevduat bankalarından ise 3'ü sabit getiriye sahipken, 5'inin ise artan getiriye sahip oldukları görülmektedir.

2016 yılında BCC-I yaklaşımında incelenen 3 katılım bankasından 1'i etkin çıkarken, 8 özel sermayeli mevduat bankasından 3'ü yeterli etkinlik değerine ulaşmıştır. $\mathrm{Bu}$ yılda analize dahil edilen bankalardan çoğunluğunun (\%64) yeterli etkinlik skoruna ulaşamadıkları görülmektedir.

2016 yılında süper etkinlik sonuçlarına göre en etkin banka Anadolubank A.Ş. olmuştur. Etkin çalışan bankalar içinde en az etkin bulunan banka ise Akbank T.A.Ş.'dir.

2016 yılı ölçek getiri türleri incelendiğinde katılım bankalarından 2'inin sabit getiriye sahip olduğu diğer birinin ise artan getiri altında çalıştığı görülmektedir. Özel sermayeli mevduat bankalarından ise 5'i sabit getiriye sahipken, 3'ünün ise artan getiriye sahip oldukları görülmektedir.

2017 yılında BCC-I yaklaşımında incelenen 3 katılım bankasından 1'i etkin çıkarken, 8 özel sermayeli mevduat bankasından 4'ü yeterli etkinlik değerine ulaşmıștır. $\mathrm{Bu}$ yılda analize dahil edilen bankalardan çoğunluğunun (\%55) yeterli etkinlik skoruna ulaşamadıkları görülmektedir.

2017 yılında süper etkinlik sonuçlarına göre en etkin banka Turkish Bank A.Ş. olmuştur. Etkin çalışan bankalar içinde en az etkin bulunan banka ise Akbank T.A.Ş.'dir.

2017 yılı ölçek getiri türleri incelendiğinde hem analize dahil edilen tüm katılım bankalarının hem de özel sermayeli mevduat bankalarının tamamının sabit ölçekte çalıştıkları görülmektedir. 
2018 yılında BCC-I yaklaşımında incelenen 3 katılım bankasından 1'i etkin çıkarken, 8 özel sermayeli mevduat bankasından 3'ü yeterli etkinlik değerine ulaşmıştır. Bu yılda analize dahil edilen bankalardan çoğunluğunun (\%64) yeterli etkinlik skoruna ulaşamadıkları görülmektedir.

2018 yılında süper etkinlik sonuçlarına göre en etkin banka Anadolubank A.Ş. olmuştur. Etkin çalışan bankalar içinde en az etkin bulunan banka ise Kuveyt Türk Katılım Bankası A.Ş’dir.

2018 yılı ölçek getiri türleri incelendiğinde katılım bankalarından 1'inin sabit getiriye sahip olduğu diğer ikisinin ise artan getiri altında çalıştığı görülmektedir. Özel sermayeli mevduat bankalarından ise 2'si sabit getiriye sahipken, 6'sının ise artan getiriye sahip oldukları görülmektedir.

\section{KAYNAKÇA}

Ahmad, S. \& Abdulrahman, A. (2012). "The Efficiency of Islamic and Conventional Commercial Banks in Malaysia", International Journal of Islamic and Middle Eastern Finance and Management, 5(3):241-263.

Algahtanı, F.; Mayes, D. G. \& Brown, K. (2017). "Islamic Bank Efficiency Compared to Conventional Banks During the Global Crisis in the GCC region", Journal of International Financial Markets, Institutions \& Money, 2017(51):58-74.

Arabacı, H. (2018). 'Türkiye'de Bankacılık Sektörünün Gelişimi (2000-2016)”, Meriç Uluslararası Sosyal ve Stratejik Dergisi, 2(3):25-42.

Arslan, R. \& Hotamışlı, M. (2007). "Türk Bankacılık Sisteminde Kurumsal Çevrenin Bankaların Yapı ve Uygulamaları Üzerinde Oluşturduğu Teşvik ve Kısıtlamalar", Yönetim ve Ekonomi Dergisi, 14(1):196-208.

Atukalp, M. E. (2018). “Özel Sermayeli Mevduat Bankalarının Finansal Performanslarının İncelenmesi: Türkiye Örneği”, Global Journal of Economics and Business Studies, 7(14):3852.

BANIXA, Frontier Analyst Data Envelopment Analysis software, How Data Envelopment Analysis Works,https://banxia.com/frontier/resources/how-data-envelopment-analysis-works/, adresinden 22.12.2019 tarihinde edinilmiştir.

Büyükakın, F \& Kapkara, S. (2016). "Katılım Bankalarının Veri Zarflama Yöntemi İle Verimlilik Ve Etkinlik Analizi Üzerine Bir Değerlendirme (2010-2015) Dönemi”, Uluslararası Yönetim, Ekonomi ve Politika Kongresi Bildiriler Kitabı, ICOMEP 2016, 493-515. İstanbul.

Doğan, M. (2013). "Katılım ve Geleneksel Bankaların Finansal Performanslarının Karşılaştırılması: Türkiye Örneği”, Muhasebe ve Finansman Dergisi, Nisan/2013:175-188.

https://www.bankalar.org/ozel-sermayeli-bankalar/, adresinden 01.01 .2020 tarihinde edinilmiştir.

Johnes, J.; Izzeldin, M. \& Pappas V. (2012). "A Comparison of Performance of Islamic and Conventional Banks 2004 to 2009", Journal of Economic Behavior \& Organization, 103(1):93-117.

Ersoy, N. (2018). “Banka Etkinliklerinin Veri Zarflama Analizi İle Değerlendirilmesi”, Finans Ekonomi ve Sosyal Araştırmalar Dergisi (FESA), 3(2), 478-487.

Ftiti, Z.; Nafti, O. \& Sreiri, S. (2013). "Efficiency Of Islamic Banks During Subprime Crisis: Evidence Of GCC Countries", 2013 The Journal of Applied Business Research, 29(1):285-304.

Hazıroğlu, T. (2016). “Türkiye’de Katılım Bankacılığı Fikrinin Doğuşu ve Kavramsal Önemi”, İslam Ekonomisi ve Finansı Dergisi, 2(1):119-132.

Huguenin, J.M. (2012). “Data Envelopment Analysis (DEA) A pedagogical guide for decision makers in the public sector", IHDEAP, Chair of Public finance, 276(2012), 
https://serval.unil.ch/resource/serval:BIB_0FC432348A97.P001/RE, adresinden 22.12.2019 tarihinde edinilmiştir.

Karaca, K. K.; Ekşi, İ. H. \& Altemur, N. (2019). “Türkiye'deki Katılım Bankalarının Etkinlik Analizi”, Gümüşhane Üniversitesi Sosyal Bilimler Enstitüsü Elektronik Dergisi, 10(2):280-290.

Lorcu, F. (2010). "Malmquist Toplam Faktör Verimlilik Endeksi: Türk Otomotiv Sanayi Uygulaması”, İstanbul Üniversitesi İşletme Fakültesi Dergisi, 39(2):276-289.

Özden, Ü. H. (2008). "Veri Zarflama Analizi (VZA) ile Türkiye'deki Vakıf Üniversitelerinin Etkinliğinin Ölçülmesi", Istanbul University Journal of the School of Business Administration, 37(2):167-185.

Öztürk, D.; Canbaz, M. F. \& Gür, M. (2017). "Katılım Bankaları ile Mevduat Bankalarının 20092016 Yılları Etkinliklerinin Vza İle Karşılaștırılması", Sosyal ve Beşeri Bilimler Araştırmaları Bildiriler Kitabı, INES 2017, 328-337, Antalya.

Paço, L. C. \& Perez, J. M. (2013). "The use of DEA (Data Envelopment Analysis) Methodology to Evaluate the Impact of ICT on Productivity in the Hotel Sector", https://journals.openedition.org/viatourism/1005 adresinden 20.12.2019 tarihinde edinilmiştir

Saeed, S.; Ali, F.; Adeeb, B. \& Hamid, M. (2013). "Examining Efficiency of Islamic and Conventional Banks in Pakistan: Using Data Envelopment Analysis", Global Journal of Management and Business Research, 13(10):25-34.

Seiford, M.L. \& Tone, K. (2007). "The CCR Model and Production Correspondence" https://www.researchgate.net/publication/319518317,adresinden 20.12.2019 tarihinde edinilmiştir.

Sucu, Ö. (2019). "Katılım Bankaları İle Mevduat Bankalarının Finansal Performansı Üzerinde Etkili Olan Faktörlerin Belirlenmesi: Türk Bankacılık Sektörü Üzerine Bir Araştırma”, Yüksek Lisans Tezi, İstanbul Üniversitesi Sosyal Bilimler Enstitüsü, İstanbul.

Sufian, F. (2007). "The Efficiency of Islamic Banking Industry in Malaysia: Foreign vs Domestic Banks", Humanomics, 23(3):174-192.

TBB, Türkiye Bankalar Birliği, www.tbb.org.tr., 20.12.2019

TKBB, Türkiye Katılım Bankaları Birliği, www.tkbb.org.tr/veri-seti. 20.12.2019

Tone, K. (2004). "Malmquist Productivity Index", Handbook on Data Envelopment Analysis, National Graduate Institute for Policy Studies, Chapter 8:203-227.

Vincova, K. (2005). "Using Dea Models to Measure Efficiency", BIATEC, Narodna Banka Slovenska, BIATEC, 2005(8):24-28.

Yaşa, A. (2008). "Bankacılık Sektöründe Etkinlik Ve Veri Zarflama Analizi Yöntemi İle Ölçülmesi”, Yüksek Lisans Tezi, Ankara Üniversitesi, Sosyal Bilimler Enstitüsü, Ankara.

Yue, P. (1992). "Data Envelopment Analysis and Commercial Bank Performance: A Primer with Applications to Missouri Banks". Federal Reserve Bank of St Louis Review, 74(1): 31-45.

Yurttadur, M. \& Demirbaş, H. (2017). “Türkiye'de Bulunan Katılım Bankaları ve Özel Sermayeli Mevduat Bankalarının Finansal Performanslarının Karşılaştırılması", İGÜ Sosyal Bilimler Dergisi, 4(2):89-117. 